Disponível em:

http://editora.unoesc.edu.br/index.php/race

RACE, Joaçaba, v. 17, n. 1, p. 9-28, jan./abr. 2018

\title{
PREPARING A CHANGE LABORATORY INTERVENTION: WASTE MANAGEMENT IN A UNIVERSITY HOSPITAL
}

\author{
Preparando uma intervenção do Laboratório de Mudança: a gestão dos resíduos de um \\ hospital universitário
}

Marcio Pascoal Cassandre

E-mail: mcassandre@hotmail.com

Pós-doutor pela Danish School of Education da Aarhus University; Doutor em Administração pela Universidade Positivo; Professor no Programa de Pós-graduação em Administração e do Departamento de Administração da Universidade Estadual de Maringá. Endereço para contato: Avenida Colombo 5.790, DAD/UEM, Bloco C-23, $2^{\circ}$ andar, Sala 203, Zona 7, 87020-900, Maringá, Paraná, Brasil.

\section{Carine Maria Senger \\ E-mail: carine.senger@gmail.com} Mestre em Desenvolvimento pela Universidade Regional do Noroeste do Estado do Rio Grande do Sul; Doutoranda no Programa de Pós-graduação em Administração da Universidade Estadual de Maringá; Professora no Colegiado de Administração da Universidade Estadual do Paraná - Campus Apucarana.

\section{Marco Antonio Pereira Querol}

E-mail: mapquero@gmail.com

Doutor em Educação de Adultos pela

Universidade de Helsinque; Mestre em Manejo de Conhecimento Agroecológico e Mudança Social pela Wageningen University, WUR, Holanda; Professor no Departamento de Engenharia Agronômica e no Programa de Pós-graduacão em Administração da Universidade Federal de Sergipe.

Artigo recebido em 02 de agosto de 2017. Aceito em 18 de outubro de 2017. 
Abstract

Researchers, interventionists and managers are challenged to plan an intervention for the development of an activity. To this purpose, it is necessary to understand and negotiate the object of the intervention with the participants. This task can be facilitated through the elaboration of a research scheme used as a planning and learning tool among interventionists and participants. This article presented an outline of such scheme for future application of a Change Laboratory (CL). This lab is considered a method to provide the development of the solid waste management activity in a university hospital in Paraná State, Brazil. The study shows the aspects to be explored to plan a CL in order to develop a new concept of this activity. It is a draft for the planning of these methodology sessions. Its preparation makes use of preliminary ethnographic data collected during the beginning of the investigative procedure foreseen by CL, seeking the current conflict historical understanding.

Keywords: Activity Theory. Change Laboratory. Waste Management. University Hospital.

\section{Resumo}

Pesquisadores, intervencionistas e gestores são desafiados a planejar uma intervenção visando ao desenvolvimento de uma atividade. Para tanto, faz-se necessário entender e negociar o objeto da intervenção com os participantes. Tal tarefa pode ser facilitada por meio da elaboração de um esquema usado como instrumento de planejamento e aprendizagem entre intervencionista e participantes. Neste artigo apresentou-se um esboço deste esquema para a aplicação futura de um Laboratório de Mudança (LM). Este laboratório é considerado um método para propiciar o desenvolvimento da atividade de gestão de resíduos sólidos em um hospital universitário do Paraná. O estudo mostra os aspectos a serem explorados para planejar um LM visando desenvolver um novo conceito dessa atividade. Trata-se de um rascunho para o planejamento das sessões dessa metodologia. Sua elaboração faz uso de dados etnográficos preliminares coletados durante o início do processo investigativo previsto pelo LM, buscando a compreensão histórica da atual situação do conflito.

Palavras-chave: Teoria da Atividade. Laboratório de Mudança. Gestão de Resíduos. Hospital Universitário.

\section{INTRODUCTION}

This article aims to contribute to the solution of the challenge faced by managers and interventionists to prepare interventions that radically transform an activity. This activity is related to the waste management of a public university hospital that has increased its costs with the disposal of its contaminated waste generated in medical and hospital activities. The initial conflict presented by the Hospital Waste 
Management Group is that employees, patients and their companions have discarded materials that show no traces of contamination in garbage baskets designed for this purpose. However, after an initial survey from the invited group to develop an intervention using a method called Change Laboratory in this hospital, it was found that the mixture of waste also occurs in recyclable and common garbage baskets. Contaminated material remains are also discarded improperly in these garbage baskets, preventing the recycling of materials that have this possibility and offering risks to the community when the contaminated items are discharged in common garbage baskets.

An emergency problem is the steady increase of waste management cost, which currently stands at an average of R \$13,000.00/month. According to the managers, the cost is mainly due to incorrect separation of waste by workers, and job accidents related to the bad waste separation.

This paper presents an outline of a Scheme of an Intervention Project using the theoretical and methodological tool called Change Laboratory (CL), based on the Theory of Historical and Cultural Activity. The CL is the application of a formative methodology in order to have a collaborative construction of radical transformations in activity systems. This proposal is illustrated with a first draft for intervention at the hospital mentioned above, to try to solve the conflict in the waste management.

According to Virkkunen and Newnham (2013), the planning of an intervention by the Change Laboratory can be divided into three levels and phases. The first phase is to build, using the dialogue with the client-organization representatives (managers, doctors, and nurses), a shared initial idea of the intervention object, dealing directly with the responsible people for activity in order to make the implementation of the intervention.

In the case of the university hospital, this dialogue happened during several meetings from September 2013, date of the first project presentation to June 2014. During these meetings, representatives of the activity and the researchers invited to the CL installation discussed about the problems and the current challenges of activity and waste management in the hospital. The result of these negotiation meetings was the preparation of a proposal for intervention. The proposal was prepared by the researchers, presented and approved by the hospital management.

The process of intervention and learning has started since the first contact with hospital representatives. During the dialogue between researchers and professionals from the client-organization there was an exchange of theoretical concepts from the researchers and ideas and concepts from the managers and professionals. In this 
context, the researcher in his research role, starts to know better what is happening in the activity, while the professionals begin to have the first contact with the methodology.

At the time of this article elaboration, the intervention was in the mirror data collection process. These data are being used for the preparation and development of a Project Scheme that will be used to perform and specify the intervention. Such a tool could be useful also as a negotiation tool and as a guide for an intervention. This draft defines the intervention and the preliminary support to the project by the professionals who will participate in the process.

This article is divided into six parts, including this introduction. The first one explains the Change Laboratory. Then it is described the research strategy for the moment of the hospital demand mapping. The next section presents the topics for the composition of the Project Scheme. The fifth part shows the Project Scheme of the CL hospital. Finally, it is presented the final considerations on this article.

\section{CHANGE LABORATORY}

According to Pereira-Querol, Jackson Filho and Cassandre (2011); Cassandre, Pereira-Querol and Bulgacov (2012) and Cassandre and Pereira-Querol (2014), the Change Laboratory (CL) is the name given to a set of concepts and methodological principles that can be used in collaboration between researchers and professionals in order to make deep changes or incremental surface transformations at work. It was developed in the 90s by a group of researchers from the Research Center on Activity, Development and Learning (CRADLE), from University of Helsinki, Finland (ENGESTRÖM et al., 1996). The concepts that justify it are based on the Activity Theory, developed by the Russian psychology, based on Vygotsky's works (1978, in ENGESTRÖM, 1999).

The CL is a specific type of interventionist methodology that Engeström (2011) calls the training methodology. This method makes use of a series of concepts based on a theoretical and methodological approach of the Activity Theory (ENGESTRÖM, 1987, 1999, 2011), including: The Human Actions Cultural Mediation Theory; The Dual Stimulation Method; The activity Model System; and Expansive Learning Theory.

The minimum unit of analysis adopted in CL is an Activity System, which incorporates the unit to understanding human actions. Besides the comprehension that the subject uses cultural artifacts in the transformation of the object, it is also included 
the mediators who were not covered previously, such as social elements, rules, labor division and community (Figure 1).

The Change Laboratory aims to facilitate the Expansive Learning. Engeström (1987, for a more recent review see ENGESTRÖM; SANNINO, 2010) proposes that the historical development of an Activity System - relatively stable for the other and qualitatively different and more advanced - occurs in five qualitatively different phases (ENGESTRÖM, 1987, p. 82-92, 189). In each stage, a different type of internal contradiction drives development. Expansive learning refers to the process in which people collectively create a new object and reason for their activities, as well as new tools and forms of social organization to resolve contradictions that put the activity in crisis.

Figure 1 - Activity System Model

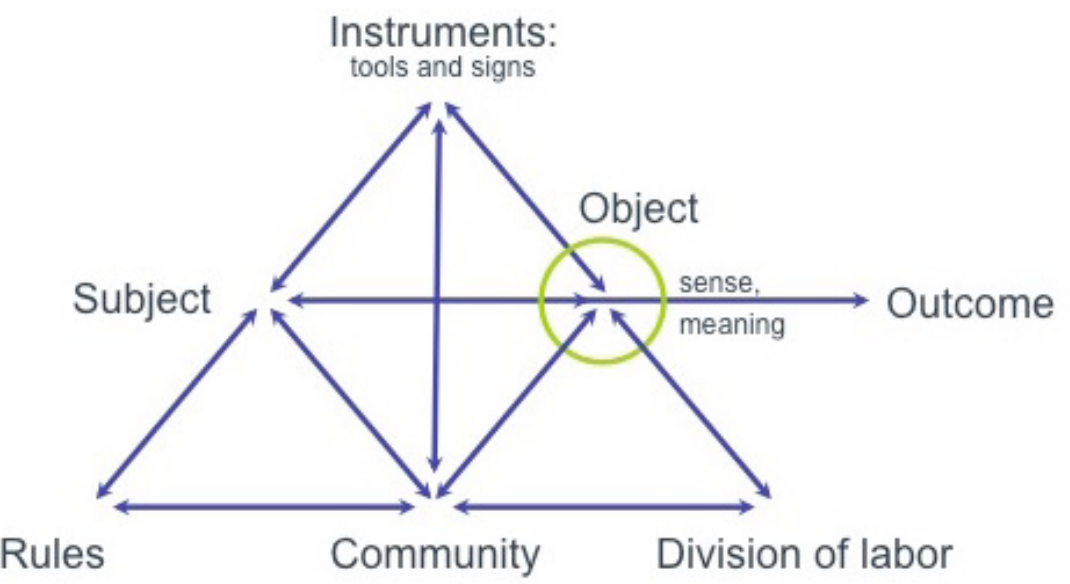

Source: Engeström (1987).

The elements presented in this model can be defined as: Subject: refers both to an individual as a subgroup of people in which their positions and points of view are chosen as analytical perspective. Object: it is understood as the meaning, the reason and the purpose of a collective activity system. The object is considered by Engeström and Blackler (2005) as a raw material for individuals involved in an activity and being open to several and partial interpretations. This raw material which contains a certain conflict or problem to be solved; it is seen as arising from the constant interpretations, reconstructions and changes driven by the subjects' action, concerning to reveal, therefore, the contradictory feature and history of change of the systems involved in the activity production. Tools: it is all mediator instruments of the subjects' action including physical or symbolic form, external and internal. Community: 
includes all individuals or subgroups that have the same object of the activity in question. Labor division: it is the division of tasks among the individuals, the hierarchical relationships, delegation of power and permanent submission to the group, besides the conflicts, resistance manifestations, status and others. Rules: refer to the regulations, the rules, the conventions related to the context of the activity that show an implicit or explicit form in the activity under review.

In the Change Laboratory, the general models of an Activity System and the Expansive Learning Cycle are used as tertiary psychologically tools (WARTOFSKY, 1979), in other words, tools that enable professionals to reflect in a collaboratively way on the system of their activity. The CL can be understood as a learning activity, or an activity which object is at the same time, the analysis and the development of a productive activity.

The method is composed of six phases, which are based on the Expansive Learning Cycle and consists in six expansive learning actions: questioning, analysis, design, testing of a new model, implementation of the new model, reflection on the process and consolidation of new actions (Figure 2).

The proposed intervention in CL is based on the organization, in the workplace, a space in which is available representation tools for analyzing disturbances and to build new models of activity (ENGESTRÖM, et al., 1996). The interventions consist in a limited number of participants, between 12-15 activities representative people beyond the interventionist and an assistant. The role of the interventionist is to present the material to be discussed and facilitate discussions. The assistant helps during the intervention, for example, in data collection and the use of video projection equipment. Among the participants, it is chosen a rapporteur responsible for taking notes of the discussions content and possible conclusions during the sections. The purpose of these notes is to have a second stimulus for the other sessions.

According to Pereira-Querol, Jackson Filho and Cassandre (2011), the process begins with the data collection on: the situation of activity, such as historical data about important events; the current practices (how the activity is conducted); the main problems faced; and 4) the main concepts and tools used in the activity.

The function of these data is twofold: to be used during the sessions as a mirror of the activity, and help the interventionist and participants to model and analyze the past, present and future activity. The sessions begin with an analysis of data about the problems daily faced, identifying the systemic causes of the observed problems that are, as emphasized above, expressions of inherent contradictions or among activity systems. During the sessions of the CL, participants produce future vision of the 
activity, which is not only based in a classification of what is desired and what is not desired. The CL, the view is based on analysis of the activity system structure that could help solve internal contradictions to the system in question.

Once participants analyzed the problem, the interventionist helps to model new solutions. Again, the interventionist provides tools to assist in this process. The new models are implemented and tested, the sessions are organized to evaluate and reflect about new solutions and potential problems that may arise during the implementation of the solutions. Adjustments and changes in the model are common in order to adapt it to the local conditions.

Figure 2 - Phases of the Expansive Development Process during the Change Laboratory

\section{Consolidating the new practice}

\section{Reflecting on the} process

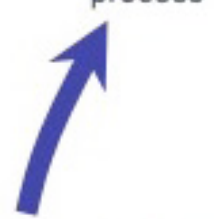

\section{Questioning}

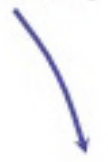

5. Implementing the new

2. Analysis model

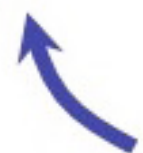

4. Examining the new model

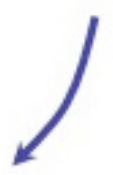

3. Modeling the new solution

Source: Engeström (1987).

The CL is a space rich in instruments in order to participants analyze and develop their activities. A key tool is the Multiple Layers Panel that is divided horizontally into three columns in order to represent the different levels of abstraction and generalization. In the horizontal position, the panel is divided into three layers representing the past, present and future of the activity being developed (ENGESTRÖM et al., 1996; ENGESTRÖM, 2007). 


\section{SEARCH STRATEGY FOR THE PHASE OF SITUATION MAPPING}

From the research project members' participation in two monthly meetings of the Hospital Management Group in question, being they on September $5^{\text {th }} 2013$ and June $5^{\text {th }}$ 2014, it was possible to build the pilot tool for the first part of the ethnographic research held in this hospital.

The ethnographic research has the intention to rescue the historical and cultural aspects related to the waste management resulting from the provision of hospital services. As strategy of this research, it was chosen the non-participant observation as a means of data collection. To this end, two teachers and four students from Administration (Business) course were characterized as medical professionals, so that the identification as researchers were minimized and therefore the true picture of the situation would be better captured, making it impossible to skew the data. For this, it was established a relay among the members of the collection so that all areas of each hospital sector were observed at two different times, with different pairs.

Being built collectively with the members of the project, the instrument was applied in Emergency Care (EC) of the hospital, because it was identified as the place with more movement of people and thus greater outbreak of conflicts and contradictions related to the topic. The strategy adopted for the data collection was that the members stand next to the local waste baskets, attentive to every possible detail to be captured. It was observed the interaction of professionals, patients and caregivers with the most diverse types of waste.

In this observation, the instrument foresaw five moments: a) quantification of waste baskets and the presence or absence of type of waste identification as: common, contaminated, recyclable, needle box, hampers, bomb for liquids and others; b) observation of the disposal during the occurrence; c) observation if it was done properly; d) opening the waste baskets to take pictures of them; e) the removing of bags containing these local waste disposal during the observation.

Observations were recorded directly on the instrument and in a field book for extra notes and equipments for photographic recording and controlling the time. Thus, on June $24^{\text {th }} 2014$, the members arranged in pairs went to the places previously mapped to the pilot collection, taking 40 minutes for the application. The chosen places were: the emergency room; suture room; and medication room.

After the pilot application, it was verified the need to adapt the instrument for definitive data collection. These changes occurred after the identification of in loco 
needs, observed and found during the application. Thus, the official beginning of data collection, using the definitive instrument, happened on July $2^{\text {nd }} 2014$, in the following locations: semi-ICU (Intensive Care Unit); the observation room; orthopedics; pediatrics; infirmary I; and infirmary II.

The following collection occurred on July $10^{\text {th }} 2014$, when teachers and students have continued the application of the instrument in places where the data collection had not been performed yet, namely: the nurses' station; hallway I; hallway II; offices; observation room I; and observation room II. By considering the nurses' station a place of great movement, materials handling and movement of professionals, it was used 40 minutes for the application. In the other areas, 20 minutes for a fast collection. Then, the first collection was completed in all the hospital areas.

At the same day began the second data collection being carried out a rotation of teachers and students, taking care that they do not collect data in the same places where they have been previously. Thus, the instruments were applied in the following places: Semi-ICU; the emergency room and medication room, having time delimitation in 40 minutes.

\section{TOPICS TO BE APPROACHED IN A PROJECT SCHEME}

The Project Scheme is a way to make concrete and specify the object of intervention, with three basic functions in the Change Laboratory. It helps to identify problems and challenges that will require further and deeper analysis. The scheme also serves as a tool to reveal how the CL intervention is related to the strategies, policies and practices of the organization. The scheme should explore the changes that are occurring and projects that are in parallel development. Finally, the scheme also helps to define the structure and purpose of the intervention (VIRKKUNEN; NEWNHAM, 2013).

In the CL, the Project Scheme is wider than a conventional project proposal, since it has to collect some basic data. Following it is presented the questions and the themes recommended by Virkkunen and Newnham (2013) to be taken into account in the preparation of the Project Scheme. 


\subsection{PRELIMINARY DEFINITION OF THE NEED FOR INTERVENTION AND ITS OBJECT}

In an organization, the need for change is usually formulated as problems faced on a daily basis. According to Virkkunen and Newnham (2013) it is necessary to differentiate between themes and activity. Themes refers to the way the problem is manifested, for example, the cost increasing of waste management, incorrect separation of waste by workers or work accidents related to bad separation of waste. The activity is related to the activity system or an activity systems network that will be the object of the intervention. In order to identify an activity it is necessary to identify the activity object and the elements that compose the activity system.

The need to transform the activity and a CL intervention can be mapped by discussing: a) the most important changes that have occurred, occur or should occur in the activity; b) the opinion of managers about the strategic objectives; c) observations related to the lack of success, customer dissatisfaction, problems and difficulties experienced in the activity; d) initiatives and ideas of how to proceed in the development of the activity; e) the places where changes and new challenges are more pronounced.

Then the researcher can explore the different theories, concepts and assumptions about how the activity in question should work. The researcher can also explore examples of successful cases that can provide idea and tools to develop the activity in question.

\subsection{EXPLAIN THE CL DEVELOPMENT PRINCIPLE TO THE PARTICIPANTS}

As explained above, the CL is based on an approach of the Theory of Historical-Cultural Activity, containing principles and specific concepts. It is important that these principles are explained to the participants, such as ascension method from abstract to the concrete. In practice, this means understanding the contradictions that affect an activity and develop a new principle or concept for the activity in order to contribute to the resolution of these contradictions. Depending on the stage of development that the activity may be, it is necessary to rethink the purpose of the activity. This new principle, which makes feasible the activity, is applied to a pilot unit and subsequently accomplished in other units. 
The principle of ascension from the abstract to the concrete makes CL different from other intervention methods. Usually, in interventions, the solutions are prepared in a centralized way and applied in different units. Thus, the cost / unit of a solution creation decrease, since it is applied in several units in a relatively short period of time. In the CL the main result is a new principle and no ready solution applicable to all units. The generalization of the newly discovered principle requires adapting the concrete conditions of each locality. These differences should be clarified to the intervention participants (VIRKKUNEN; NEWNHAM, 2013).

\subsection{SELECTION OF THE PILOT UNIT}

In the CL, the problems are understood with expression of contradictions between the elements of an activity system and between activity systems. Therefore, the initial job is to reveal these contradictions, which explain the appearance of everyday problems. According to Virkkunen and Newnham (2013), the discovery of these contradictions is easier in units that are experiencing harder challenges. Another important criterion for the selection of the pilot unit, besides the worsening of contradictions, is that the professionals in the local unit express interest and have the capacity and the resources needed to develop its activity. Thus, it is not enough that the unit is identified or suggested by the managers, it is also necessary to involve the professionals of this activity in the decision and choice of the unit, since joining the process is voluntary.

Virkkunen and Newnham (2013) suggest some questions to be discussed in order to define the pilot unit:

a) What unit or local instance of the activity intensely experience the need for change?

b) What unit or activity is in a central position on the subsequent expansion and the development of a new activity model?

c) In what unit the management and staff are interested in developing a new activity model and able to do it with the assistance of external researchers-interventors?

d) In what unit the situation is established and stable enough in order to have de execution of the Change Laboratory process? 


\subsection{PARTICIPANTS SELECTION}

According to Virkkunen and Newnham (2013), the key principle in the selection of participants for the CL is that they are dealing with the same object in their daily work, as well as being involved in achieving the same results. In the case of a hospital, for example, it is necessary to invite all those people who are working directly with residues; patients' representatives, nurses, doctors, cleaning workers etc. However, it is important to take into account that exceed 20 people could impair a more open and direct discussion. If this number is exceeded it is recommended the formation of sub-groups.

\subsection{DEFINING THE INTERVENTION SCOPE AND FREQUENCY}

As reported by Virkkunen and Newnham (2013), the sessions of CL should be intense and continuous. It is suggested that should happen twelve weekly sessions of two hours in consecutive weeks, and a period that lasts four to six weeks for the first experiments with the newly produced solutions having the sequence some monitoring sessions of the changes evolution produced by the Change Laboratory. The continuity of the sessions is important in order to advance in the learning process, otherwise the participants take the chance of forgetting what was covered in the previous meeting, thus failing to advance in the process.

\subsection{CONNECTION WITH THE MANAGEMENT STRATEGIES}

The success of a CL intervention requires that this is connected to the ongoing discussion about the activity strategic management. Therefore, Virkkunen and Newnham (2013) recommend the formation of a committee or an advisory group that could help researchers in the intervention planning and direction.

\section{THE PROJECT SCHEME AT THE UNIVERSITY HOSPITAL}

The project scheme presented here is the product of dialogue and negotiation among researchers, administration and the Management Group of solid waste from the hospital. The initial contact with the researchers happened with the heads of the 
Management Group who knew CL methodology participating in an event where the work results using this methodology were presented.

In order to the dialogue and the negotiation happen, two meetings were held, being the first on September 05 ${ }^{\text {th }}$ 2013, whose participants were the members of the project and members of the Management Group among them several health professional and general services workers, totalizing approximately 25 people. This meeting aimed to present theoretical aspects of the collaborative transformation tool of work activities: Change Laboratory in order that all were aware of this methodology, since the intention of those responsible for the Management Group was applying it at the hospital.

Besides the theoretical aspects approached by the member of the project in this meeting, the members of the Management Group had the opportunity to discuss practical aspects related the imminent conflict, highlighting, based on covered theoretical aspects: who should learn? Why learning? How to learn? And What learning?

According to the discussion of the members, who should learn is the hospital unit as a whole, because beyond the legal requirement, there is a need to reduce costs, change paradigms, improve the quality of life, and work (Why learning?)

For this, they suggested a leveling of knowledge about waste management, and from this, the transfer of this knowledge to train the other actors, culminating with the monitoring and continuity of the learning process, since there are no ongoing actions (How to learn?). Finally, they highlighted that "what learning” was related to what is the University Hospital, its mission, its vision, its values, what wastes are generated, the legal requirement about it and how to work in teams with diverse and multidisciplinary profiles.

Based on the discussions of this meeting, it was prepared the research project that was submitted for a hospital managers' review. This project was the starting point for the definition of the Project Scheme. Thus, the Hospital Administration held the second meeting after the approval of the project on June $5^{\text {th }} 2014$. As it happened at the previous meeting, in this participated the members of the project and Management Group members, totalizing approximately 20 people.

Because they are not the same members who participated in the previous meeting, this meeting it was necessary to rescue the theoretical aspects of the CL methodology. Then the Management Group also rescued historical aspects of the creation and performance of the Group, which has existed since 2001 to deal with waste management and comply with legal requirements. Finally, in the meeting it was 
discussed about the probable place where would be collected the mirror data and who would be the possible participants in the CL.

\subsection{THE NEED OF CHANGE}

During the meeting on July $5^{\text {th }} 2014$ with the Management Group were discussed possible causes of the problems and solutions. According to the management representative, one of the causes is the no adequate waste separation by employees. When asked why employees do not separate, the reason stated by the representative was that "they do not separate because they know that recyclable and non-recyclable waste ending up being all mixed in the final destination.”

Then, the responsible worker for the waste collection from different units of the hospital said that the waste is mixed, because there is no buyer for recyclables. Recyclers do not want to buy the hospital recyclable for two reasons: the waste is not well separated and often inside the bags are needles and other objects used in patients, generating risk of contamination in the collecting people, and there is no market for recycled material, such as syringes packaging. Currently, the only recycled material is the paperboard.

At the meeting with the Waste Management Group of the hospital, it was commented about the influence of the high turnover in the waste management. The turnover make with there are employees without specific knowledge to properly handle the waste. People who receive training usually leave the hospital, creating a constant demand for training. However, the positive aspect of high turnover is that new people do not have the old habits that often prevent the change.

The Diagram 3 tries to summarize the vicious circle that leads to increase the volume of waste and consequently the increase of waste management costs.

The activity refers to the activity system or network activity systems that will be the object of intervention. During the meeting, it was discussed about the activity object of the intervention, which was considered the activity of solid waste management. 
Diagram 3 - Vicious Cycle Scheme of Bad Waste Separation at the University Hospital

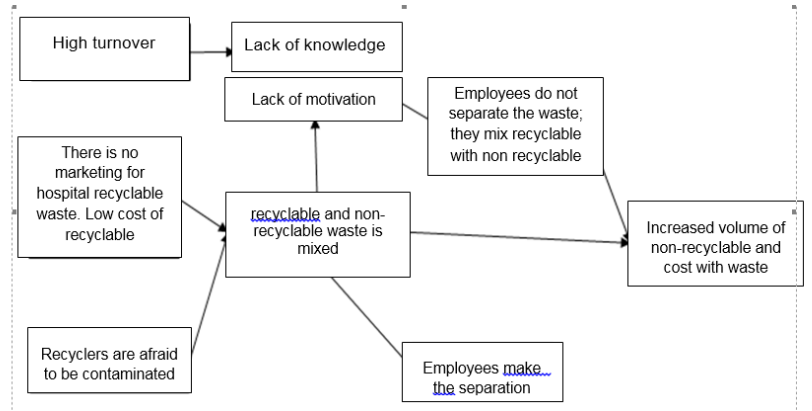

Source: the authors.

When asked if the Management Group was enough, and if this group influenced the attitudes of the people in order to change in relation to the waste. An employee says no, because consider that people should have more involvement, especially hospital staff, including doctors, nurses, administrators, pharmacists, since they do not seem to value the programs proposed by the Waste Management Group due to all the other responsibilities they already have with patients, and the tasks related to their duties.

This employee highlights that is necessary the participation of the largest possible number of professionals operating within the hospital for a good management and to the inclusion of other workers in the innovations proposed by the Management Group. In her opinion, “[...] the hospital lost almost "thirteen thousand real” due to improper separation of materials, so it is essential the participation of all sectors to a good organization of the hospital, both the financial costs and to prevent damage to the environment and to the hospital.”

\subsection{DEVELOPMENT ATTEMPTS AND EXAMPLES OF MORE DEVELOPED ACTIVITIES}

When they were asked about past attempts to solve the problem, members of the Management Group remembered initiatives and educational campaigns to explain about the importance of waste separation performed. According to the members, the campaigns bring results in the short term, but the long-term employees return to worsen the separation. A campaign that they used presented a photo exhibition of materials found in the laundry room showing materials offering risk to the cleaning staff.

An interesting example of waste management activity that can be considered more developed is the waste management at the Blood Center of this hospital. The 
responsible person by the Quality Management told that this sector has achieved ISO 9000 certification and, with that, it was designed the protocol for waste management. From this moment it began to be made trainings that have been covered the basic concepts of this management, and Quality Management staff was responsible for solving problems or doubts that each worker had in this sector. There is a biannual internal audit in this Waste Management, where a committee formed by these professionals is distributed in different areas of the hospital and do an analysis of how the employee is putting in practice the waste management.

After the internal audit, they are raised the errors and suggestions for improvement; for every "error" there is a non-compliance, where they seek the real causes of these failures and apply the corrective action plan. In Blood Center this process is already settled, but the challenge is to lead this process standardization to the other areas. According to responsible person for this sector, the sectors that have conditions to develop such changes are the Laboratory, the Pharmacy and the Intensive Care Units, which are units that are more organized.

During the meetings with the Administration and the Management Group it was emphasized the differences between the CL and traditional methods. The participants were accustomed to the traditional method which the interventionist imposes solutions. It was clarified that in the CL not only the solutions are constructed by the participants but also the formulation of the problem.

\section{FINAL CONSIDERATIONS}

It is important to highlight that the Project Scheme presented is in a planning process. According to the activity schedule presented in the research project, it is in accomplishment the Activity 1: Waste Management Diagnostics (Data collection) and planning, with expected completion in September 2014.

It is considered this activity essential to the historical survey of the subject in question, the identification of the key people who will attend the CL, as well as for the further analysis and planning of interventions, being necessary to set when these will be performed. Only after the conclusion of this activity, it will start the Activity 2: Historical analysis of the conflict situations in relation to the waste management diagnosed initially. Then, this will be followed by Activity 3: Problems Analysis; Activity 4: Elaboration and implementation of the challenges hypothesis to sustainable development; Activity 5: Intervention Planning; scheduled to be completed in October 2014. 
The implementation of Activity 6: Intervention Conduction (initial proposal of 12 sessions), with the application of CL methodology, is expected to be held between November 2014 and February 2015. After this intervention, the project forwards for its completion to the implementation of Activity 7: the new distribution planning model of new practices in the University Hospital departments and the analysis of sessions that happening in the activity, to be developed in March and April 2015. The last planned activity, the Activity 8: Creation of tools to follow the created innovations and formalization of the group for permanent monitoring of new conflicts generated by the new model estimated for May, June and July 2015 and conclude the project.

The pilot selection is still under negotiation. The unit that experiences intensely the need for change is the Emergency Hospital Care. However, there are still doubts about the interest of employees in developing a new model of activity and if there is a sufficiently stable situation to perform the Process of Change Laboratory.

On the other hand, the selection of participants is under discussion and analysis, highlighting the importance of having representatives people from the Hospital Management Group, as well as key people, but not members of this group, such as directly responsible for municipal waste management, prosecutors and especially hospital administration representatives.

It is evaluated to be important the creation of this Project Scheme, in order to the planning, execution and control of CL phases are backed with sufficient data and information for the laboratory development occurs in a more concrete and grounded way. Otherwise, the researchers, when build this scheme, come to better understand the locus of the research, besides the people and the contradictions involved in the activity.

Finally, it isdesired that the academic community could contribute to the improvement of this work, bringing new points of view and other directions that strengthens the realization of this project that is one of the first CL initiatives in the Administration area in Brazil.

\section{REFERENCES}

CASSANDRE, M. P.; PEREIRA QUEROL, M. A. P.; BULGACOV, Y. L. M. Metodologias Intervencionistas: Contribuição Teórico-metodológica dos Princípios Vigotskyanos para Pesquisa em Aprendizagem Organizacional. In: ENCONTRO DA ASSOCIAÇÃO NACIONAL DE PÓS-GRADUAÇÃO E PESQUISA EM ADMINISTRAÇÃO, 26., 2012, Rio de Janeiro. Anais... Rio de Janeiro: Anpad, 2012. 1 CD-ROM. 
CASSANDRE, M. P.; PEREIRA QUEROL, M. A. P. Metodologias Intervencionistas: Contribuição Teórico-Metodológica Vigotskyanas Para Aprendizagem Organizacional. Revista Pensamento Contemporâneo em Administração, UFF, v. 8, p. 17-34, 2014.

ENGESTRÖM, Y. Activity theory and individual and social transformation. In: ENGESTRÖM, Y.; MIETTINEN, R.; PUNAMÄKI, R. L. (Org.). Perspectives on activity theory. Cambridge: University Press, 1999.

ENGESTRÖM, Y.; BLACKLER, F. On the life of the object. Organization, v. 12, i. 3, p. 307-330, 2005.

ENGESTRÖM, Y. et al. The change laboratory as a tool for transforming work. Lifelong Learning, Europe, v. 1, 1996.

ENGESTRÖM, Y. From design experiments to formative interventions. Theory \& Psychology, v. 21, i. 5, p. 598-628, 2011.

ENGESTRÖM, Y. Learning by expanding: an activity-theoretical approach to developmental research. Orienta-KonsultitOy, 1987.

ENGESTRÖM, Y. Putting Vygotsky to work: The change laboratory as an application of double stimulation. In: DANIELS, H., COLE, M.; WERTSCH, J. M. (Org.). The Cambridge companion to Vygotsky. England: Cambridge University Press Cambridge, 2007.

ENGESTRÖM, Y.; SANNINO, A. Studies of expansive learning: Foundations, findings and future challenges. Educational Research Review, v. 5, i. 1, p. 1-24, 2010.

PEREIRA QUEROL, M.; JACKSON FILHO, L.; CASSANDRE, M. P. Change Laboratory: uma proposta metodológica para pesquisa e desenvolvimento da Aprendizagem Organizacional. Administração: Ensino e Pesquisa, v. 12, 2011.

VIRKKUNEN, J.; NEWNHAM, D. The Change Laboratory: a Tool for Collaborative Development of Work and Education. Sense Publishers, 2013.

WARTOFSKY, M. W. Models: Representation and the scientific understanding. Dordecht: Reidel, 1979. 


\section{Como citar este artigo:}

ABNT

CASSANDRE, Marcio Pascoal; SENGER, Carine Maria; PEREIRA QUEROL, Marco Antonio. Preparing a Change Laboratory intervention: waste management in a university hospital. RACE, Revista de Administração, Contabilidade e Economia, Joaçaba: Ed. Unoesc, v. 17, n. 1, p. 9-28, jan./abr. 2018. Disponível em: <http:// editora.unoesc.edu.br/index.php/race>. Acesso em: dia/mês/ano.

\section{APA}

Cassandre, M. P., Senger, C. M., \& Pereira Querol, M. A. (2018). Preparing a Change Laboratory intervention: waste management in a university hospital. RACE, Revista de Administração, Contabilidade e Economia, 17(1), 9-28. Recuperado em dia/mês/ano, de http://editora.unoesc.edu.br/index.php/race 
